\title{
The alpha-Gal syndrome: new insights into the tick-host conflict and cooperation
}

\author{
José de la Fuente ${ }^{1,2^{*}}$, Iván Pacheco ${ }^{1}$, Margarita Villar ${ }^{1}$ and Alejandro Cabezas-Cruz ${ }^{3}$
}

\begin{abstract}
This primer focuses on a recently diagnosed tick-borne allergic disease known as the alpha-Gal syndrome (AGS). Tick bites induce in humans high levels of IgE antibodies against the carbohydrate Gala1-3Galß1-(3)4GlcNAc-R (a-Gal) present on tick salivary glycoproteins and tissues of non-catarrhine mammals, leading to the AGS in some individuals. This immune response evolved as a conflict and cooperation between ticks and human hosts including their gut microbiota. The conflict is characterized by the AGS that mediate delayed anaphylaxis to red meat consumption and certain drugs such as cetuximab, and immediate anaphylaxis to tick bites. The cooperation is supported by the capacity of anti-a-Gal IgM and IgG antibody response to protect against pathogens with a-Gal on their surface. Despite the growing diagnosis of AGS in all world continents, many questions remain to be elucidated on the tick proteins and immune mechanisms triggering this syndrome, and the protective response against pathogen infection elicited by anti-a-Gal antibodies. The answer to these questions will provide information for the evaluation of risks, diagnosis and prevention of the AGS, and the possibility of using the carbohydrate a-Gal to develop vaccines for the control of major infectious diseases.
\end{abstract}

Keywords: Tick, Allergy, Alpha-Gal syndrome, Vaccine, Immune response

\section{What is the alpha-Gal syndrome (AGS)?}

The main objective of our research is the characterization of vector-host-pathogen molecular interactions, and translating this basic biological information into new interventions for the diagnosis, prevention and control of vector-borne diseases [1-3] (see also video at https:// youtu.be/DhbBjQSuLYk). Arthropod vector-borne diseases are a growing problem worldwide, and ticks are only second to mosquitoes as vectors of human diseases and the most important vectors in animals [4-6].

The alpha-Gal syndrome (AGS) is triggered by IgE antibody response against the carbohydrate Galo1-3Gal $\beta 1$ (3)4GlcNAc-R ( $\alpha-G a l)$, which is present in glycoproteins from tick saliva and tissues of non-catarrhine mammals [7-13] (Additional file 1: Figure S1). In 2007, van Nunen et al. [7] first described the association between tick

\footnotetext{
${ }^{*}$ Correspondence: jose_delafuente@yahoo.com

${ }^{1}$ SaBio, Instituto de Investigación en Recursos Cinegéticos (IREC), Consejo

Superior de Investigaciones Científicas (CSIC), Universidad de Castilla-La Mancha (UCLM)-Junta de Comunidades de Castilla-La Mancha (JCCM),

Ronda de Toledo s/n, 13005 Ciudad Real, Spain

Full list of author information is available at the end of the article
}

bites and the development of mammalian meat allergy. In 2009, Commins et al. [11] confirmed this association and discovered the epitope likely responsible for such allergic reactions, $(\alpha-\mathrm{Gal})$. Old World monkeys, apes and humans evolved with the inactivation of the $\alpha-1,3-$ galactosyltransferase (GalT) gene, which resulted in the recognition of $\alpha$-Gal to produce high antibody titers against this antigen [12] (Additional file 1: Figure S1). Tick bites induce high levels of anti- $\alpha-G a l$ IgE antibodies in humans that mediate delayed anaphylaxis to red meat consumption, and immediate anaphylaxis to tick bites, xenotransplantation and certain drugs such as cetuximab $[13,14]$.

The AGS is becoming a global problem with increasing prevalence in all continents, and several tick species have been implicated in these disorders [10, 15] (Additional file 1: Figure S1). Remarkably, most of the patients that become allergic, had tolerated red meat for many years before being sensitized by tick bites [10]. This finding suggests that while IgG and IgM antibody responses to $\alpha$-Gal produced by some bacteria of the gut microbiota are beneficial as they protect against infection by pathogens such 
as malaria parasites and tuberculosis mycobacteria, anti$\alpha-G a l$ IgE antibodies induced by tick bites break the oral tolerance to food allergens and induce anaphylactic reactions to tick $\alpha$-Gal-containing salivary proteins $[7-15]$.

\section{Why only some individuals develop the AGS in response to tick bites?}

Tick saliva is a complex mixture of pharmacologically active compounds with a role in tick attachment cement and feeding, pathogen transmission, and the inhibition of host defensive mechanisms through immunomodulatory, anti-hemostatic and anti-inflammatory molecules [16-26]. Transcriptomics, proteomics and metabolomics studies of tick salivary glands, saliva and cement discovered clusters of functionally related proteins with protease inhibitors being the most abundant group of tick salivary secreted proteins in Ixodes scapularis [16, 18, 20-26]. The genes coding for some of these proteins are usually expressed sequentially throughout tick feeding, bringing up the question of whether this phenomenon could be a form of antigenic variation [16]. Tick saliva modulates host immunity towards a $\mathrm{T}$ helper $2(\mathrm{Th}-2)$ response and suppresses inflammatory responses [27], thus deviating the host immune response to profiles that are less damaging to the feeding tick and pathogen transmission. Apart from proteins with immunomodulatory activity, ticks also produce non-protein molecules such as prostaglandin E2 $\left(\mathrm{PGE}_{2}\right)$, which is synthesized in the tick salivary glands and secreted via the saliva into the feeding lesion $[26,28]$.

Humans do not synthesize the carbohydrate $\alpha$-Gal, and therefore all the sources of $\alpha-G a l$ for the human body are from non-human origin $[9,11-13,29]$. Consequently, humans can develop a potent immune response against this carbohydrate [9, 11-13, 29]. Recently, we demonstrated that ticks synthesize $\alpha-G a l$ with functional GalTs with implications of this protein modification in tick feeding and Anaplasma phagocytophilum infection [30]. Considering these facts, evidence supports a role for $\alpha$-Gal-containing tick salivary proteins in the development of the AGS, possibly in conjunction with other tick salivary components $[9,11-13,29]$. At least two possible mechanisms explain the production in humans of anti- $\alpha$ Gal IgE antibodies after tick bites (Additional file 1: Figure S1). The first mechanism is supported by our current understanding of the host immune modulation by tick saliva, and proposes that $\alpha-G a l$ on tick salivary proteins interacts with antigen-presenting cells (APC) and B lymphocytes in the context of Th2 cell-mediated immunity induced by tick saliva. Basophils and released histamine have been implicated in IgE-mediated acquired protective immunity to tick infestations and chronic itch [31-35]. This mechanism leads to the elevation of the anti- $\alpha$-Gal IgE response $[16,28]$. The second mechanism needs to be demonstrated, and is based on the possibility that tick saliva contains factors that induce class switch recombination (CSR) to anti- $\alpha-G a l$ IgE producing B cells of pre-existing $B$ cell clones producing anti- $\alpha-G a l$ IgM and/or IgG antibodies [28].

Tick salivary proteins with or without $\alpha$-Gal modifications that may be involved in triggering the AGS have not been identified, but some $\alpha$-Gal-containing proteins have been shown to be recognized by patients with anaphylactic reaction to tick bite and not by healthy individuals with a record of tick bites [14]. The characterization of tick proteins involved in AGS and the immune mechanisms triggering this syndrome is essential to answer the question of why only some individuals develop the AGS in response to tick bites [36-38] (Additional file 1: Figure S1). Tick sialome and alphagalactome profiles probably change as tick feeding proceeds thus highlighting the importance of the characterization of proteome changes during tick stages on the host to provide information on the abundance and risks associated with these proteins at different tick feeding stages. Furthermore, tick proteins present in the tick sialome and reacting with IgE in patients but not control sera could be used for the diagnosis of a predisposing condition for AGS. Tick sialome proteins with $\alpha$-Gal modification (alphagalactome) and recognized by patients but not sera from healthy individuals exposed to tick bites could be selected as candidate protective antigens for the treatment and prevention of the AGS.

Risk factors associated to AGS may include genetic/ immune mechanisms such as atopy, and ABO blood group composition leading to strong IgE response against $\alpha$-Gal after tick bite, and ecological components associated to exposure to tick bites [9, 37, 39-44]. Other factors such as alcohol consumption, physical exercise, cat ownership and infection with pet-associated endoparasites, age and use of some medications may also influence the risk of developing the AGS [37, 42]. A conjunction of these and other still unknown factors may affect the development of AGS by some individuals exposed to tick bites.

\section{Can we benefit from the risk of developing the AGS?}

Tick-host-pathogen interactions evolved as a conflict and cooperation [45]. In this context, the AGS evolved as a trade-off to benefit humans by providing immunity to pathogens containing $\alpha$-Gal while increasing the risks to develop this syndrome [12, 39] (Additional file 1: Figure S1).

Some of the major infectious diseases worldwide are caused by pathogens such as Plasmodium, 
Mycobacterium, Trypanosoma, Borrelia and Leishmania species with a common characteristic of having $\alpha$-Gal on their surface [39, 46-52]. As proposed for viruses with envelope-exposed $\alpha$-Gal as the major evolutionary driver for the lack of functional GalT for $\alpha$-Gal synthesis in humans, the possibility of developing protective antibodies against this carbohydrate resulted in an effective protection against pathogens with $\alpha-G a l$ [12]. This evolutionary advantage of humans relays on anti- $\alpha-G a l$ IgM and IgG antibodies produced in response to gut bacterial microbiota, tick infestations and/or pathogen infection with a protective effect against some infectious diseases [46-52]. However, this evolutionary cooperation between ticks and humans also leads to the conflict of increasing the risks for developing AGS in response to tick bites.

As previously proposed, we may benefit from this tickhost conflict and cooperation [46, 47] (Additional file 1: Figure S1). Gut bacteria with high $\alpha$-Gal content selected from individuals with protective immune response against pathogens with $\alpha$-Gal could be used to develop a probiotic-based easy to administer and low-cost vaccine that could by administered by different routes alone or in combination with $\alpha$-Gal-containing tick proteins to provide protection against multiple pathogens causing major infectious diseases worldwide [46, 47]. If proven true, this would be a major advance in the control of infectious diseases affecting populations in different parts of the world.

\section{Conclusions}

The AGS has been associated with tick bites and constitutes a growingly diagnosed disease worldwide. Nevertheless, many questions remain to be elucidated on the tick proteins and immune mechanisms triggering this syndrome, and the protective response against pathogen infection elicited by anti- $\alpha-G a l$ antibodies. Future research should focus at the identification of tick proteins involved in the production of anti- $\alpha$-Gal IgE antibodies after tick bite, and the immune mechanisms leading to AGS. The relationship between different tick species/ developmental stages and the AGS applying Koch's postulates in GalT negative animal models would contribute to a better understanding of the disease and the evaluation of epidemiological risks. Data on blood group type should be included in epidemiological studies to better evaluate the risks for AGS associated with blood type in the population, and the putative role of anti- $\alpha-G a l$ IgM and IgG antibodies in protection against pathogens with $\alpha$-Gal. Other factors that may affect the AGS such as endoparasite infections and microbiota composition in both humans and ticks should be considered. The answer to these questions will provide information for the evaluation of risks, diagnosis and prevention of the AGS, and the possibility of using the carbohydrate $\alpha$-Gal to develop vaccines for the control of major infectious diseases.

\section{Additional file}

Additional file 1: Figure S1. Poster of tick-host conflict and cooperation in the AGS: facts, challenges and possibilities.

\section{Abbreviations}

AGS: alpha-Gal syndrome; a-Gal: Gala1-3Galß1-(3)4GIcNAc-R; GalT: galactosyltransferase; Th-2: PGE2: Thelper 2, prostaglandin E2; APC: antigen-presenting cells; CSR: class switch recombination.

\section{Acknowledgements}

We thank members of our laboratories for fruitful discussion.

\section{Funding}

The preparation of this manuscript was partially supported by the Consejería de Educación, Cultura y Deportes, JCCM, Spain, project CCM17-PIC-036 (SBPLY/17/180501/000185). MV was supported by the University of Castilla La Mancha, Spain.

Availability of data and materials

Not applicable.

\section{Authors' contributions}

JF conceived the primer focus and outline. JF, IP, MV and AC-C contributed to the design of the poster and editing of the manuscript. AC-C contributed images for the figures in the poster. JF and IP prepared the poster. JF and AC-C wrote the manuscript. All authors read and approved the final manuscript.

\section{Ethics approval and consent to participate}

Not applicable.

Consent for publication

Not applicable.

\section{Competing interests}

The authors declare that they have no competing interests.

\section{Publisher's Note}

Springer Nature remains neutral with regard to jurisdictional claims in published maps and institutional affiliations.

\section{Author details \\ 1 SaBio, Instituto de Investigación en Recursos Cinegéticos (IREC), Consejo Superior de Investigaciones Científicas (CSIC), Universidad de Castilla-La Mancha (UCLM)-Junta de Comunidades de Castilla-La Mancha (JCCM), Ronda de Toledo s/n, 13005 Ciudad Real, Spain. ${ }^{2}$ Department of Veterinary Pathobiol- ogy, Center for Veterinary Health Sciences, Oklahoma State University, Still- water, OK 74078, USA. ${ }^{3}$ UMR BIPAR, INRA, ANSES, Ecole Nationale Vétérinaire d'Alfort, Université Paris-Est, Maisons-Alfort 94700, France.}

Received: 13 February 2019 Accepted: 27 March 2019

Published online: 03 April 2019

\section{References}

1. de la Fuente J, Contreras M, Estrada-Peña A, Cabezas-Cruz A. Targeting a global health problem: vaccine design and challenges for the control of tick-borne diseases. Vaccine. 2017;35:5089-94.

2. de la Fuente J, Antunes S, Bonnet S, Cabezas-Cruz A, Domingos A, Estrada-Peña $A$, et al. Tick-pathogen interactions and vector competence: 
identification of molecular drivers for tick-borne diseases. Front Cell Infect Microbiol. 2017;7:114.

3. de la Fuente J. Controlling ticks and tick-borne diseases ... looking forward. Ticks Tick Borne Dis. 2018;9:1354-7.

4. Jones KE, Patel NG, Levy MA, Storeygard A, Balk D, Gittleman JL, et al. Global trends in emerging infectious diseases. Nature. 2008;2451:990-3.

5. Estrada-Peña A, Ostfeld RS, Peterson AT, Poulin R, de la Fuente J. Effects of environmental change on zoonotic disease risk: an ecological primer. Trends Parasitol. 2014:30:205-14.

6. de la Fuente J, Estrada-Peña A, Venzal JM, Kocan KM, Sonenshine DE. Overview: ticks as vectors of pathogens that cause disease in humans and animals. Front Biosci. 2008;13:6938-46.

7. van Nunen S, O'Connor KS, Clarke LR, Boyle RX, Fernando SL. The association between /xodes holocyclus tick bite reactions and red meat allergy. Intern Med J. 2007;39:A132.

8. Cabezas-Cruz A, Valdés J, de la Fuente J. Cancer research meets tick vectors for infectious diseases. Lancet Infect Dis. 2014;10:916-7.

9. Steinke JW, Platts-Mills TA, Commins SP. The alpha-gal story: lessons learned from connecting the dots. J Allergy Clin Immunol. 2015;135:589-96.

10. Platts-Mills TA, Schuyler AJ, Tripathi A, Commins SP. Anaphylaxis to the carbohydrate side chain alpha-gal. Immunol Allergy Clin North Am. 2015;35:247-60

11. Commins SP, Satinover SM, Hosen J, Mozena J, Borish L, Lewis BD, et al. Delayed anaphylaxis, angioedema, or urticaria after consumption of red meat in patients with IgE antibodies specific for galactose-alpha-1,3-galactose. J Allergy Clin Immunol. 2009;123:426-33.

12. Galili U. Evolution in primates by "Catastrophic-selection" interplay between enveloped virus epidemics, mutated genes of enzymes synthesizing carbohydrate antigens, and natural anticarbohydrate antibodies. Am J Phys Anthropol. 2018;168:352-63.

13. Hilger C, Fischer J, Wölbing F, Biedermann T. Role and mechanism of galactose-alpha-1,3-galactose in the elicitation of delayed anaphylactic reactions to red meat. Curr Allergy Asthma Rep. 2019;19:3.

14. Mateos-Hernández L, Villar M, Moral A, García Rodríguez C, Alfaya Arias T, De La Osa V, et al. Tick-host conflict: immunoglobulin E antibodies to tick proteins in patients with anaphylaxis to tick bite. Oncotarget. 2017:8:20630-44.

15. Kwak M, Somerville C, van Nunen S. A novel Australian tick Ixodes (Endopalpiger) australiensis inducing mammalian meat allergy after tick bite. Asia Pac Allergy. 2018:8:e31.

16. Chmelař J, Kotál J, Kopecký J, Pedra JHF, Kotsyfakis M. All for one and one for all on the tick-host battlefield. Trends Parasitol. 2016;32:368-77.

17. Nuttall PA. Wonders of tick saliva. Ticks Tick Borne Dis. 2019;10:470-81.

18. Kim TK, Tirloni L, Pinto AF, Moresco J, Yates JR 3rd, da Silva Vaz l, et al. Ixodes scapularis tick saliva proteins sequentially secreted every $24 \mathrm{~h}$ during blood feeding. PLoS Negl Trop Dis. 2016;10:e0004323.

19. Hajdušek O, Šíma R, Ayllón N, Jalovecká M, Perner J, de la Fuente J, et al. Interaction of the tick immune system with transmitted pathogens. Front Cell Infect Microbiol. 2013;3:26.

20. Anderson JM, Moore IN, Nagata BM, Ribeiro JMC, Valenzuela JG, Sonenshine DE. Ticks, Ixodes scapularis, feed repeatedly on white-footed mice despite strong inflammatory response: an expanding paradigm for understanding tick-host interactions. Front Immunol. 2017;8:1784.

21. Kazimírová M, Štibrániová I. Tick salivary compounds: their role in modulation of host defences and pathogen transmission. Front Cell Infect Microbiol. 2013;3:43.

22. Suppan J, Engel B, Marchetti-Deschmann M, Nürnberger S. Tick attachment cement - reviewing the mysteries of a biological skin plug system. Biol Rev Camb Philos Soc. 2018;93:1056-76.

23. Hoxmeier JC, Fleshman AC, Broeckling CD, Prenni JE, Dolan MC, Gage KL, et al. Metabolomics of the tick-Borrelia interaction during the nymphal tick blood meal. Sci Rep. 2017;7:44394.

24. Ayllón N, Villar V, Galindo RC, Kocan KM, Šíma R, López JA, et al. Systems biology of tissue-specific response to Anaplasma phagocytophilum reveals differentiated apoptosis in the tick vector Ixodes scapularis. PLoS Genet. 2015;11:e1005120.

25. Abreu MR, Pereira MC, Simioni PU, Nodari EF, Paiatto LN, CamargoMathias MI. Immunomodulatory and morphophysiological effects of Rhipicephalus sanguineus s.l. (Acari: Ixodidae) salivary gland extracts. Vet Immunol Immunopathol. 2019;207:36-45.
26. Oliveira CJ, Sá-Nunes A, Francischetti IM, Carregaro V, Anatriello E, Silva $J S$, et al. Deconstructing tick saliva: non-protein molecules with potent immunomodulatory properties. J Biol Chem. 2011;286:10960-9.

27. Preston SG, Majtán J, Kouremenou C, Rysnik O, Burger LF, Cabezas-Cruz A, et al. Novel immunomodulators from hard ticks selectively reprogramme human dendritic cell responses. PLoS Pathog. 2013;9:e1003450.

28. Cabezas-Cruz A, Mateos-Hernández L, Chmelař J, Villar M, de la Fuente 」. Salivary prostaglandin E2: role in tick-induced allergy to red meat. Trends Parasitol. 2017:33:495-8.

29. Cabezas-Cruz A, Mateos-Hernández L, Pérez-Cruz M, Valdés J, Fernández de Mera IG, Villar M, et al. Regulation of the immune response to a-gal and vector-borne diseases. Trends Parasitol. 2015;31:470-6.

30. Cabezas-Cruz A, Espinosa PJ, Alberdi P, Šimo L, Valdés JJ, Mateos-Hernández $\mathrm{L}$, et al. Tick galactosyltransferases are involved in a-Gal synthesis and play a role during Anaplasma phagocytophilum infection and Ixodes scapularis tick vector development. Sci Rep. 2018;8:14224.

31. Wada T, Ishiwata K, Koseki H, Ishikura T, Ugajin T, Ohnuma N, et al. Selective ablation of basophils in mice reveals their nonredundant role in acquired immunity against ticks. J Clin Invest. 2010;120:2867-75.

32. Karasuyama $\mathrm{H}$, Yamanishi Y. Basophils have emerged as a key player in immunity. Curr Opin Immunol. 2014;31:1-7.

33. Tabakawa Y, Ohta T, Yoshikawa S, Robinson EJ, Yamaji K, Ishiwata K, et al. Histamine released from skin-infiltrating basophils but not mast cells is crucial for acquired tick resistance in mice. Front Immunol. 2018;9:1540.

34. Hashimoto T, Rosen JD, Sanders KM, Yosipovitch G. Possible roles of basophils in chronic itch. Exp Dermatol. 2018. https://doi.org/10.1111/ exd.13705.

35. Karasuyama H, Tabakawa Y, Ohta T, Wada T, Yoshikawa S. Crucial role for basophils in acquired protective immunity to tick infestation. Front Physiol. 2018;9:1769.

36. Hamsten C, Tran TAT, Starkhammar M, Brauner A, Commins SP, Platts-Mills TAE, et al. Red meat allergy in Sweden: association with tick sensitization and B-negative blood groups. J Allergy Clin Immunol. 2013;132:1431-4.

37. Fischer J, Lupberger E, Hebsaker J, Blumenstock G, Aichinger E, Yazdi $A S$, et al. Prevalence of type I sensitization to alpha-gal in forest service employees and hunters. Allergy. 2017;72:1540-7.

38. Bircher AJ, Hofmeier KS, Link S, Heijnen I. Food allergy to the carbohydrate galactose-alpha-1,3-galactose (alpha-Gal): four case reports and a review. Eur J Dermatol. 2017;27:3-9.

39. Cabezas-Cruz A, Mateos-Hernández L, Alberdi P, Villar M, Riveau G, Hermann E, et al. Effect of blood type on anti-a-Gal immunity and the incidence of infectious diseases. Exp Mol Med. 2017;49:e301.

40. Commins SP, James HR, Kelly LA, Pochan SL, Workman LJ, Perzanowski MS, et al. The relevance of tick bites to the production of IgE antibodies to the mammalian oligosaccharide galactose- $\alpha-1,3$-galactose. J Allergy Clin Immunol. 2011;127(1286-93):e6.

41. van Nunen S. Tick-induced allergies: mammalian meat allergy and tick anaphylaxis. Med J Aust. 2018;208:316-21.

42. Gonzalez-Quintela A, Dam Laursen AS, Vidal C, Skaaby T, Gude F, Linneberg A. IgE antibodies to alpha-Gal in the general adult population: relationship with tick bites, atopy, and cat ownership. Clin Exp Allergy. 2014;44:1061-8.

43. Villalta D, Pantarotto L, Da Re M, Conte M, Sjolander S, Borres MP, et al. High prevalence of SlgE to galactose-a-1,3-galactose in rural pre-alps area: a cross-sectional study. Clin Exp Allergy. 2016;46:377-80.

44. Rispens T, Derksen NI, Commins SP, Platts-Mills TA, Aalberse RC. IgE production to a-Gal is accompanied by elevated levels of specific igg 1 antibodies and low amounts of IgE to blood group B. PLoS One. 2013;8:e55566.

45. de la Fuente J, Villar M, Cabezas-Cruz A, Estrada-Peña A, Ayllón N, Alberdi P. Tick-host-pathogen interactions: conflict and cooperation. PLoS Pathog. 2016;12:e1005488.

46. Cabezas-Cruz A, de la Fuente J. Immunity to a-Gal: toward a singleantigen pan-vaccine to control major infectious diseases. ACS Cent Sci. 2017:3:1140-2

47. Cabezas-Cruz A, de la Fuente J. Immunity to a-Gal: the opportunity for malaria and tuberculosis control. Front Immunol. 2017;8:1733.

48. Galili U, Mandrell RE, Hamadeh RM, Shohet SB, Griffiss JM. Interaction between human natural anti-O-galactosyl immunoglobulin $\mathrm{G}$ and bacteria of the human flora. Infect Immun. 1988;56:1730-7. 
49. Yilmaz B, Portugal S, Tran TM, Gozzelino R, Ramos S, Gomes J, et al. Gut microbiota elicits a protective immune response against malaria transmission. Cell. 2014;159:1277-89.

50. Almeida IC, Milani SR, Gorin PA, Travassos LR. Complement-mediated lysis of Trypanosoma cruzi trypomastigotes by human anti-alpha-galactosyl antibodies. J Immunol. 1991;146:2394-400

51. Almeida IC, Krautz GM, Krettli AU, Travassos LR. Glycoconjugates of Trypanosoma cruzi: a $74 \mathrm{kD}$ antigen of trypomastigotes specifically reacts with lytic anti-alpha-galactosyl antibodies from patients with chronic Chagas disease. J Clin Lab Anal. 1993;7:307-16.

52. Moura APV, Santos LCB, Brito CRN, Valencia E, Junqueira C, Filho AAP, et al. Virus-like particle display of the a-Gal carbohydrate for vaccination against Leishmania infection. ACS Cent Sci. 2017;3:1026-31.
Ready to submit your research? Choose BMC and benefit from:

- fast, convenient online submission

- thorough peer review by experienced researchers in your field

- rapid publication on acceptance

- support for research data, including large and complex data types

- gold Open Access which fosters wider collaboration and increased citations

- maximum visibility for your research: over $100 \mathrm{M}$ website views per year

At BMC, research is always in progress.

Learn more biomedcentral.com/submissions 